\title{
Modelling kinetics of watercress (Nasturtium officinale) colour changes due to heat and thermosonication treatments
}

\author{
Rui M.S. Cruz ${ }^{a}$, Margarida C. Vieira ${ }^{b}$, Cristina L.M. Silva ${ }^{a, *}$ \\ ${ }^{\text {a }}$ Escola Superior de Biotecnologia, Universidade Católica Portuguesa, Rua Dr. António Bernardino de Almeida, 4200-072 Porto, Portugal \\ ${ }^{\mathrm{b}}$ Escola Superior de Tecnologia, Universidade do Algarve, Campus da Penha, 8005-139 Faro, Portugal
}

Keywords: Watercress (Nasturtium officinale); Heat blanching; Thermosonication; Colour changes; Chlorophylls; Kinetics modelling

\begin{abstract}
Watercress (Nasturtium officinale) colour changes due to blanching by heat and a combined treatment of heat/ultrasound (thermosonication) were studied in the temperature range of 82.5 to $92.5^{\circ} \mathrm{C}$. The application of thermosonication was intended to enable less severe blanching treatments and, therefore, improve the quality of the blanched product. The thermosonication blanching processes promoted changes of the green colour $\left(a^{\mathrm{n}}\right.$ parameter $)$ at a higher rate $(P<0.05)$, when compared with the heat blanching processes. No significant differences $(P>0.05)$ were detected between heat and thermosonication blanching processes in terms of the colour parameters $L^{\mathrm{n}}, b^{\mathrm{n}}$ and TCD changes. In both treatments, a fractional first order model fitted well the experimental data for $L^{\mathrm{n}}, a^{\mathrm{n}}$ and $b^{\mathrm{n}}\left(R_{\mathrm{H}}^{2}=0.99 ; R_{\mathrm{Ts}}^{2}=0.99\right)$ and TCD $\left(R_{\mathrm{H}}^{2}=0.92 ; R_{\mathrm{Ts}}^{2}=0.96\right)$ colour parameters.

The chlorophylls content showed no significant differences $(P>0.05)$ between thermally treated and thermosonicated watercress samples.

The present findings will help to evaluate the effectiveness of thermosonication as a novel process to replace the classical heat treatment.
\end{abstract}

Industrial relevance: Conventional blanching commonly results in severe losses or destruction of nutrients due to process intensity and extended process times. Consequently, the attempts to use the synergistic effects of heat and ultrasound (at least) for enzyme inactivation are of high relevance. The results, although not conclusive, indicate, that they may aid optimization of blanching processes.

\section{Introduction}

Watercress (Nasturtium officinale) is a vegetable, consumed raw or cooked in various kinds of recipes. Under refrigerated storage it has a short shelf-life of approximately 7 days, but by freezing a longer period for distribution and storage can be achieved. Prior to the freezing process, blanching has an important role in the inactivation of enzymes, microorganisms and in the stabilisation of colour. However, the degree of thermal treatment during blanching can also have adverse effects on the quality of frozen vegetables. It causes irreversible modifications to the cellular structure, many vitamins and minerals can leach into the blanching medium, and green chlorophylls may convert to yellow brown pheophytins. For this reason many alternative

\footnotetext{
* Corresponding author. Tel.: +35122 5580058; fax: +351225090351.

E-mail addresses: rcruz@ualg.pt (R.M.S. Cruz),mvieira@ualg.pt

(M.C. Vieira), clsilva@esb.ucp.pt (C.L.M. Silva).
}

methods have been developed, but the conventional hot water blanching is commonly used (Katsaboxakis, 1984).

The colour quality attribute strongly influences the consumer in the acquisition of the final product. In order for colour to be quantified objectively, the visual observing components needed to be taken into account are the object, light and the observer (Hunter Lab, 2000).

Colour can be measured by a tristimulus colorimeter, represented by three co-ordinates in the colour scale. The $L$ parameter represents lightness ( $L=0$ black; $L=100$ white), $a$ (red to green) and $b$ (blue to yellow) (Ávila \& Silva, 1999; Francis \& Clydesdale, 1975; Lau, Tang, \& Swanson, 2000; Martins \& Silva, 2002; Nisha, Singhal, \& Pandit, 2004; Tijskens, Schijvens, \& Biekman, 2001).

In the thermal processing of green vegetables, changes in colour, from bright green to olive green, are the result of the conversion of chlorophylls into pheophytins and pyropheophytins (Ihl, Monsalves, \& Bifani, 1998; Lau et al., 2000; Martins 
\& Silva, 2002; Nisha et al., 2004; Rocha, Lebert, \& MartyAudouin, 1993; Tijskens et al., 2001; Woolfe, 1979).

Chlorophyll is a fat soluble tetrapyrrole pigment, occurring in chloroplasts of green plants, photosynthetic bacteria and algae (Priestley, 1979). It plays a fundamental role in the photosynthesis, being capable of converting sunlight into chemical energy (Luh \& Woodroof, 1988). The most important forms of chlorophyll are chlorophyll $a$ and chlorophyll $b$, occurring in an approximate ratio of 3:1 (Weemaes, Ooms, Van Loey, \& Hendrickx, 1999). The difference in the composition of the sidechain (in $a$ it is $-\mathrm{CH}_{3}$, in $b$ it is $-\mathrm{CH}=\mathrm{O}$ ) causes each type of chlorophyll to absorb light at slightly different wavelengths. There are two major absorption bands in visible spectrum, in blue (around $400 \mathrm{~nm}$ ) and red (around $660 \mathrm{~nm}$ ).

When vegetables are blanched, an initial brightening of the colour is observed, due to the removal of gases and air around fine hairs on the surface of the leaves, and the expulsion of air from extracellular space (Priestley, 1979). With further heating, an undesirable fading of the colour from bright green to olive brown appears, attributed to the loss of the central magnesium atom in the tetrapyrrole ring (Schwartz \& von Elbe, 1983). The latter component is very labile, especially at low values of $\mathrm{pH}$. During the blanching treatment, organic acids are released from plant tissues, thus causing a $\mathrm{pH}$ decrease and consequential conversion of chlorophylls to pheophytins (Murcia, LópezAyerra, Martnez-Tomé, \& García-Carmona, 2000).

To minimize the adverse effects of heating on quality, alternative methods of blanching, or combinations of the conventional heat treatment with other physical factors, such as ohmic blanching (Icier, Yildiz, \& Baysal, 2006) or microwave blanching (Ihl et al., 1998) have been developed.

One of the alternative methods might be the thermosonication blanching, which is a combined treatment with heat and ultrasound. High energy ultrasound $(18 \mathrm{kHz}-100 \mathrm{kHz})$ has been applied for enzyme inactivation (Knorr, Zenker, Heinz, $\&$ Lee, 2005). This enzyme inactivation is achieved probably as a result of a phenomenon called cavitation (Mason, Paniwnyk, \& Lorimer, 1996; Vercet, Burgos, Crelier, \& Lopez-Buesa, 2001), which means the formation, growth and sometimes implosion of microbubbles created in a liquid, when ultrasound waves propagate through it (Mason et al., 1996).

The synergistic effect of the combined heat and ultrasound treatment allows inactivating several enzymes at lower temperatures and/or in shorter time (Vercet et al., 2001). The combined treatment heat/ultrasound (thermosonication) is useful in the inactivation of the enzyme peroxidase in watercress at less severe heat blanching conditions (Cruz, Vieira, \& Silva, 2006). However, there is lack of studies on the evaluation of the thermosonication treatments effect on products quality, and particularly on watercress visual colour.

Therefore, the main objective of this work was to study the effect of the blanching conditions, using a combined treatment of heat and ultrasound, on watercress colour changes. The findings will help to evaluate the effectiveness of thermosonication blanching as a novel process to at least partly replace the classical heat treatment.

\section{Materials and methods}

\section{Raw material}

Raw watercress was kindly supplied by Vitacress, a company that grows watercress in Almancil, Algarve-Portugal. The leaves were selected, washed thoroughly and analysed within 24 h. Table 1 presents the initial characteristics of the raw watercress.

\section{$\mathrm{pH}$ determination}

Based on the method reported by the Health Canada-Official Method (1999), two grams of raw watercress were homogenized in $20 \mathrm{ml}$ of degassed water, with an Ultra-Turrax T25 Janke and Kunkel, for $1 \mathrm{~min}$ at $13500 \mathrm{rpm}$. The samples were extracted on a mechanical shaker (Edmund Bühler 7400 Tübingen KL2) for 30 min. Afterwards, samples were kept in the dark for an additional hour. The supernatant was decanted and $\mathrm{pH}$ (pH meter Crison micropH 2002) was measured in ten replicates.

\section{Water activity and water content determinations}

The water activity was measured with an $a_{\mathrm{w}}$ meter (Rotronic-Hygroskop Dt-Probe WA-14 TH, sensor DMS $100 \mathrm{H}$ ) in a thermostatic circulator water bath (LKB Broma 2219), set at $25 \pm 0.1^{\circ} \mathrm{C}$. The experiments were run with triplicates.

The water content was measured in ten replicates, using an infrared dryer (Mettler LP16) set at $140{ }^{\circ} \mathrm{C}$.

\section{Thermal and thermosonication blanching processes}

Each sample of watercress $(3 \mathrm{~g})$ was processed in individual conical flasks with $100 \mathrm{ml}$ of distilled water, in a water bath Grant W14, with temperatures ranging from 82.5 to $92.5{ }^{\circ} \mathrm{C}$, with different times of exposure.

The combination of heat/ultrasound was applied to the watercress at the same range of temperatures and sampling times. The samples were blanched with an ultrasound horn (Coleparmer V1A; $13 \mathrm{~mm} \mathrm{dia)} \mathrm{at} 20 \mathrm{kHz}$ and an ultrasound generator (Coleparmer 4710 Series) radiating $125 \mathrm{~W}$ of power. After each treatment, the samples were cooled in an iced water bath (Cruz et al., 2006).

Table 1

Initial characteristics of raw watercress

Colour

$L$

$a$

$b$

Chlorophyll a $\left(\mu \mathrm{g} \mathrm{g}^{-1}\right)$

Chlorophyll b $\left(\mu \mathrm{g} \mathrm{g}^{-1}\right)$

Total chlorophylls $\left(\mu \mathrm{g} \mathrm{g}^{-1}\right)$

$\mathrm{pH}$

Water activity $\left(a_{\mathrm{w}}\right)$

Water content $(\%)$
$37.456 \pm 1.824$

$-9.661 \pm 1.075$

$12.255 \pm 1.277$

$602.821 \pm 120.083$

$246.213 \pm 27.235$

$849.034 \pm 141.574$

$6.500 \pm 0.003$

$0.994 \pm 0.003$

$91.227 \pm 0.472$ 


\section{Colour measurement}

Colour was evaluated in terms of $L, a$ and $b$ values, with a tristimulus Dr. Lange Spectro-colour colorimeter in the Hunter system (Hunter Lab, 2000). The colorimeter $\left(\mathrm{d} / 8^{\circ}\right.$ geometry, illuminant D65, $10^{\circ}$ observer) was calibrated against a standard ceramic white tile $(X=84.60, Y=89.46$, $Z=93.85)$ and a standard ceramic black tile $(X=4.12$, $Y=4.38, Z=4.71)$. Measurements were taken in triplicates with ten readings each.

The total colour difference (TCD) was evaluated, where $L_{0}$, $a_{0}$ and $b_{0}$ are the readings at time zero, and $L, a$ and $b$ the individual readings at each processing time.

$\mathrm{TCD}=\sqrt{(\Delta L)^{2}+(\Delta a)^{2}+(\Delta b)^{2}}$

$\Delta L=L-L_{0}$

$\Delta a=a-a_{0}$

$\Delta b=b^{-} b_{0}$

To minimize the variability between different raw samples, the individual $L, a$ and $b$ values were normalised, dividing the parameters by the corresponding initial values.

$L^{n}=\frac{L}{L_{0}} ; a^{n}=\frac{a}{a_{0}} ; b^{n}=\frac{b}{b_{0}}$

\section{Kinetics modelling}

Colour is often described by first order reaction (Ahmed, Kaur, \& Shivhare, 2002; Baik \& Mittal, 2003; Barreiro, Milano, \& Sandoval, 1997; Ibarz, Pagán, \& Garza, 1999; Lau et al., 2000; Nisha et al., 2004; Rattanathanalerk, Chiewchan, \& Srichumpoung, 2005), or fractional conversion (also known as reversible first order) reaction models (Eq. (4)), (Ávila \& Silva, 1999).

The reversible first order reaction model was used to describe colour changes in watercress:

$\frac{C-C_{e}}{C_{0}-C_{e}}=e^{-k t}$

where $C$ is the $L^{\mathrm{n}}, a^{\mathrm{n}}, b^{\mathrm{n}}$ or TCD parameters (i.e. dependent variable) at time $\mathrm{t}$ (independent variable), $C_{0}$ the corresponding initial value at time equal to zero, and $C_{e}$ its final value at the equilibrium. The blanching time is represented by $t$, and $k$ is the reaction rate.

The reaction rate temperature dependence followed the Arrhenius behaviour:

$k=k_{\mathrm{ref}} e^{\left[-\frac{E_{a}}{R}\left(\frac{1}{T}-\frac{1}{T_{\text {ref }}}\right)\right]}$ where $k_{\text {ref }}$ is the reaction rate at the reference temperature, $E_{\text {a }}$ the activation energy, $R$ the universal gas constant, $T$ the absolute temperature, and $T_{\text {ref }}$ the reference temperature.

By substitution, Eq. (4) can be expressed as:

$\left.\frac{C-C_{\mathrm{e}}}{C_{0}-C_{\mathrm{e}}}=e^{\left\{-k_{\text {ref }}\left[-\frac{E_{\mathrm{a}}}{R}\left(\frac{1}{T}-\frac{1}{T_{\mathrm{ref}}}\right)\right]\right.}\right\}$

\section{Chlorophylls content determination}

For chlorophylls extraction, $80 \%$ aqueous acetone (Merck) solution was prepared by mixing 8 parts of $100 \%$ acetone reagent grade with two parts of ultra pure water $(\mathrm{v} / \mathrm{v})$. A solution of oxalic acid (2\%) was prepared by mixing $2 \mathrm{ml}$ of saturated oxalic acid (Merck) with $98 \mathrm{ml}$ of $80 \%$ aqueous solution of acetone.

The samples were analysed based on the method reported by Weemaes et al. (1999), with some modifications. The samples $(3 \mathrm{~g})$ were mixed in $20 \mathrm{ml}$ of the $80 \%$ acetone solution and homogenised with an Ultra-Turrax (T25-Janke and Kunkel) during approximately $2 \mathrm{~min}$. The homogenates were centrifuged (Sigma 3K20) at $34.882 \times g$ and $4{ }^{\circ} \mathrm{C}$ during $5 \mathrm{~min}$. The pellet was washed with $20 \mathrm{ml}$ of $80 \%$ acetone solution and centrifuged until it was decolourised. The extracts were then filtered through filter paper Whatman n.1, with a Büchner funnel under vacuum. From each extract solution unconverted and converted samples were prepared.

Unconverted (non-acidified) samples were prepared by diluting $0.12 \mathrm{ml}$ of extract solution in $3 \mathrm{ml}$ of $80 \%$ acetone solution. The converted (acidified) samples were run by mixing $0.12 \mathrm{ml}$ of extract solution with $1.5 \mathrm{ml}$ of oxalic acid (2\%) and $1.5 \mathrm{ml}$ of $80 \%$ acetone solution, to convert chlorophylls to pheophytins. All samples were kept in the dark at room temperature for $3 \mathrm{~h}$, and then the absorbance was recorded, using $10 \mathrm{~mm}$-path-length glass cells (Amersham Biosciences) in an UV/vis spectrophotometer (Hitachi U-2000). The solution of $80 \%$ acetone and a solution of oxalic acid $2 \%$ with $80 \%$ acetone with a ratio of $1: 1(\mathrm{v}: \mathrm{v})$ were used as a blank to zero the instrument, respectively for unconverted and converted samples.

All samples were run in triplicate and kept in the dark during the time of preparation and analysis.

Chlorophylls $a$ and $b$ concentrations were calculated using a procedure developed by Vernon (1960), as follows:

Chlorophyll $a(\mu \mathrm{g} / \mathrm{ml})=25.38(\Delta A 662)+3.64(\Delta A 645)$

Chlorophyll $b(\mu \mathrm{g} / \mathrm{ml})=30.38(\Delta A 645)+6.58(\Delta A 662)$

The abbreviations $\Delta A 645$ and $\Delta A 662$ stand for change in absorbance of non-acidified and acidified sample at $645 \mathrm{~nm}$ and $662 \mathrm{~nm}$, respectively. 
The final pigment concentrations were expressed in $\mu \mathrm{g}$ per $\mathrm{g}$ of fresh product.

\section{Statistical analysis}

A one step non-linear regression was performed, fitting Eq. (6) to the $L^{\mathrm{n}}, a^{\mathrm{n}}, b^{\mathrm{n}}$ and TCD experimental data colour parameters, reaction rate at the reference temperature and activation energy were estimated using the statistical software STATA version 6.0 (Stata Corp., 1999). The reference temperature used was the average value of the range considered (i.e. $T_{\text {ref }}=87.5{ }^{\circ} \mathrm{C}$ ), aiming at improving parameter estimation. Parameters' precision was evaluated by confidence intervals at $95 \%$, and the quality of the regression was assessed by the coefficient of determination $\left(R^{2}\right)$, and randomness and normality of residuals, thus allowing best model selection.

Two-factor (heat and thermosonication) analysis of variance (ANOVA) was carried out, to test any significant differences between chlorophylls/pheophytins in raw and blanched samples. (Arabshahi \& Lund, 1985). Initial and equilibrium values of

\section{Results and discussion}

The $L^{\mathrm{n}}$ and $b^{\mathrm{n}}$ parameters decreased in both treatments (conventional or thermosonication blanching), showing that the samples after blanching were darker and less yellow (Figs. 1 and 3 , respectively). The normalised $a^{\mathrm{n}}$ values increased right at the beginning of the blanching treatment, reaching a "plateau" after some time of exposure, meaning that the samples were greener (Fig. 2). For both treatments, when compared with raw watercress, the processing led to great colour differences, reaching at equilibrium TCD values between 6 and 12 (Fig. 4). A fractional conversion model with Arrhenius temperature dependence (Eq. (6)) fitted well the experimental data for TCD $\left(R_{\mathrm{H}}^{2}=0.92\right.$; $\left.R_{\mathrm{Ts}}^{2}=0.96\right)$ and the $L^{\mathrm{n}}, a^{\mathrm{n}}$ and $b^{\mathrm{n}}$ parameters $\left(R_{\mathrm{H}}^{2}=0.99\right.$; $\left.R_{\mathrm{Ts}}^{2}=0.99\right)$. No significant differences $(P>0.05)$ were detected between heat and thermosonication blanching processes in terms of $L^{\mathrm{n}}, b^{\mathrm{n}}$ and TCD parameters (Figs. 1, 3 and 4, respectively). However, significant differences $(P<0.05)$ were detected in the reaction rate at the reference temperature of the $a^{\mathrm{n}}$ parameter change between blanching treatments. Tables 2 and 3 present the kinetic
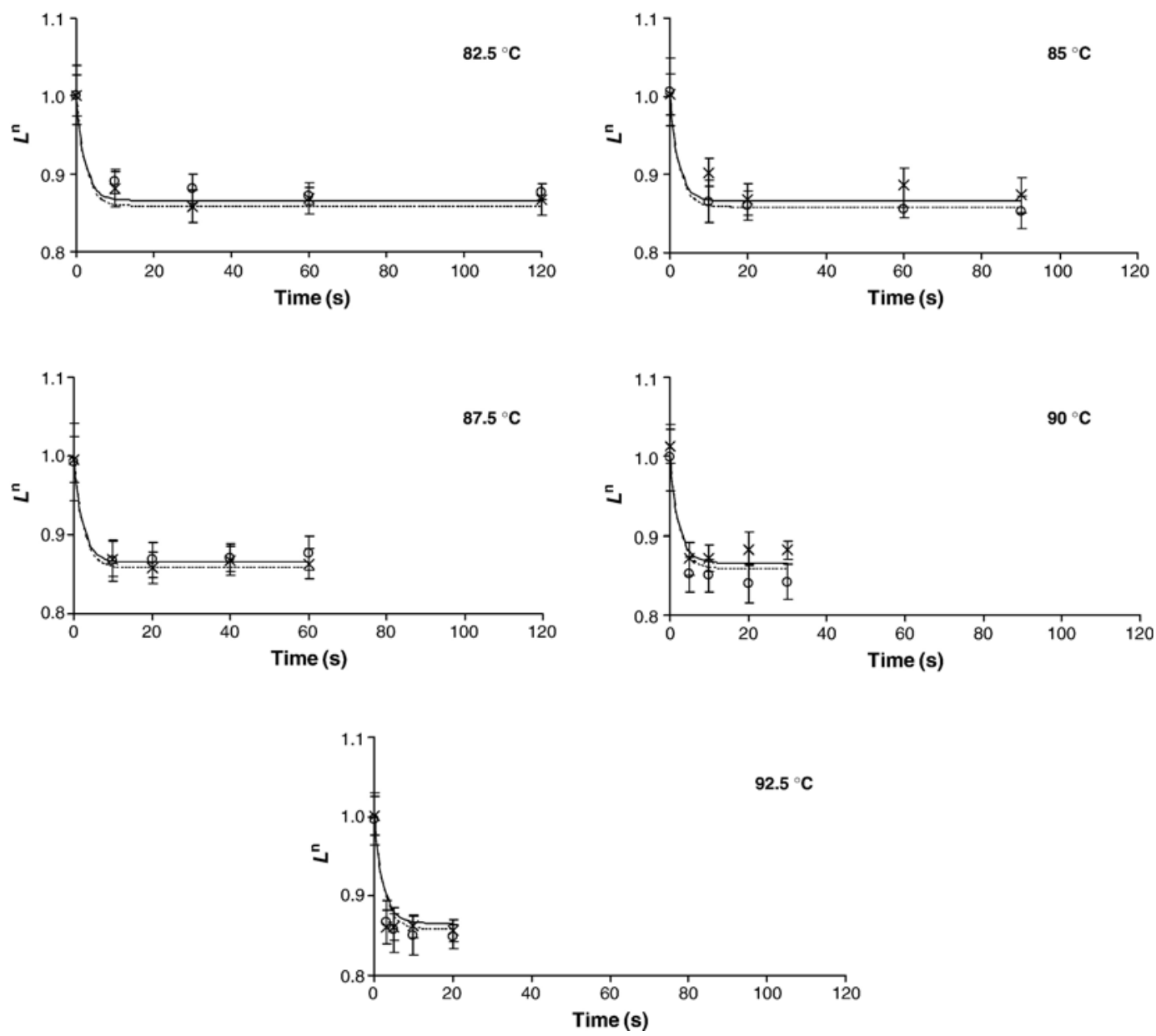

Fig. 1. Effect of temperature, ultrasound and time on $L^{\mathrm{n}}$ parameter of watercress, in the temperature range of 82.5 to $92.5^{\circ} \mathrm{C}$ : (x) experimental values with heat blanching processes; (-) model predicted values for heat blanching processes; (o) experimental values with thermosonication blanching processes; (---) model predicted values for thermosonication blanching processes. Bars represent mean \pm standard deviation. 

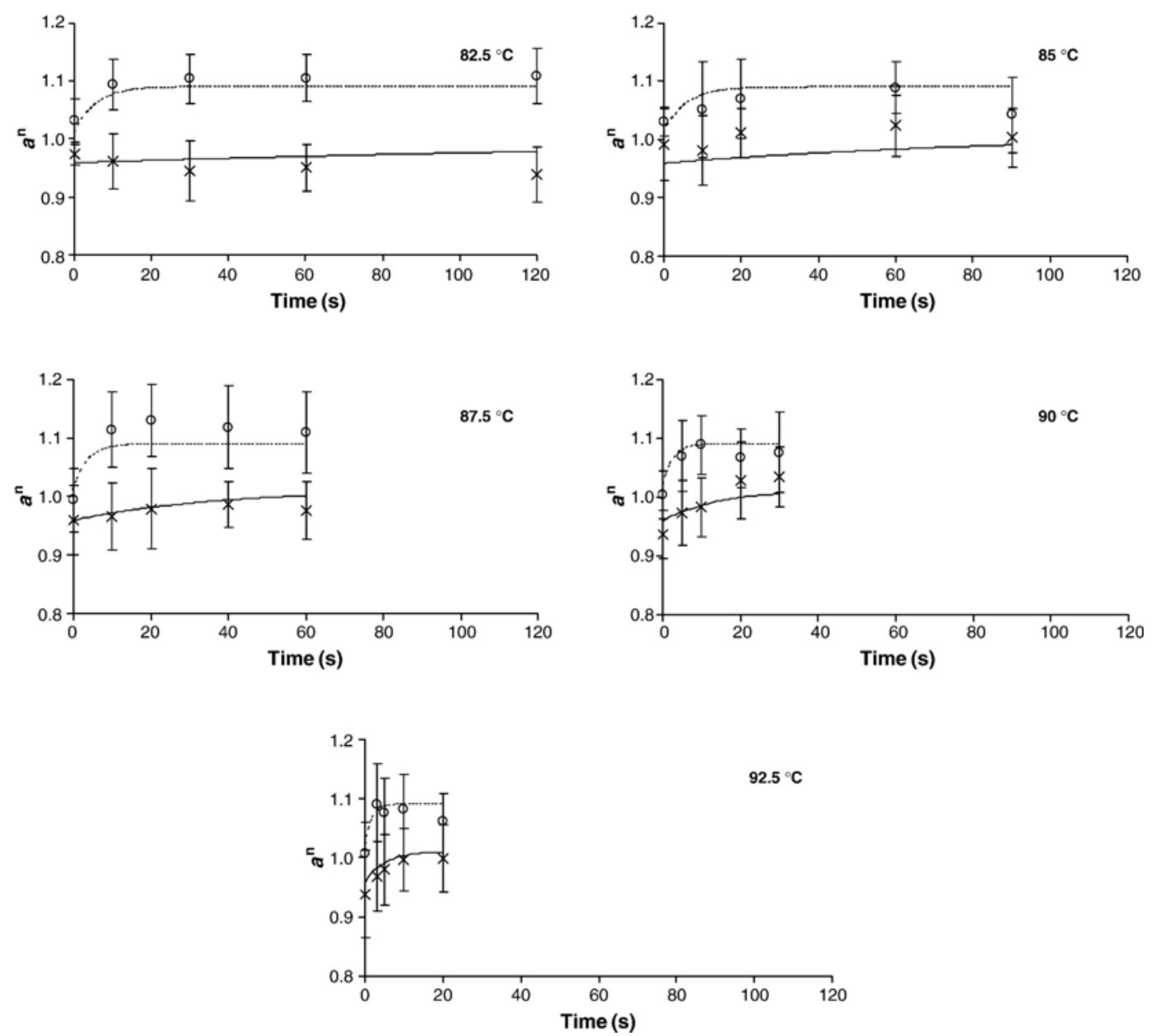

Fig. 2. Effect of temperature, ultrasound and time on $a^{\mathrm{n}}$ parameter of watercress, in the temperature range of 82.5 to $92.5^{\circ} \mathrm{C}$ : $(\mathrm{x})$ experimental values with heat blanching processes; (-) model predicted values for heat blanching processes; (o) experimental values with thermosonication blanching processes; (---) model predicted values for thermosonication blanching processes. Bars represent mean \pm standard deviation.

model parameters, respectively for conventional and thermosonication blanching treatments.

The thermosonication blanching processes promoted changes of the green colour ( $a$ parameter) at a higher rate, when compared with the heat blanching processes (Fig. 2).

The thermosonication has also been shown to be more effective in watercress peroxidase inactivation (Cruz et al., 2006) Therefore, for this enzyme inactivation, a thermosonication treatment may be used to minimize colour changes, since processing times can be reduced. It should be also remarked that instead of promoting colour degradation, the applied thermosonication treatments led to greener watercress samples.

These results are in agreement with those reported by Di Cesare, Forni, Viscardi, and Nani (2004), in which leaves of oregano became also greener after blanching. Lin and Brewer (2005) showed, in a study with frozen peas that after microwave and water blanching the peas were also greener. Brewer, Begum, and Bozeman (1995) reported significant darkening of stems and florets of broccoli after microwave blanching. Tijskens et al. (2001) presented similar effects on green colour of blanched broccoli and green beans, and Icier et al. (2006) in pea puree water blanching. These colour changes may be related to the replacement of the gases inside the intercellular spaces by the blanching medium, altering light refraction from the cell surface (Bowers, 1992).

In previous studies, a wide variation in the activation energies was found for colour degradation of vegetables and fruits. The obtained activation energies for TCD in watercress with heat and thermosonication were, respectively, $267.16 \pm 113.28 \mathrm{~kJ} \mathrm{~mol}^{-1}$ and $281.80 \pm 190.25 \mathrm{~kJ} \mathrm{~mol}^{-1}$. An activation energy of $62.51 \mathrm{~kJ} \mathrm{~mol}^{-1}$ for pear puree was reported by Ibarz et al. (1999), and for peach puree a value of $119.9 \mathrm{~kJ} \mathrm{~mol}^{-1}$ was presented by Ávila and Silva (1999). Comparing the results with those reported by Ahmed et al. (2002), for TCD in blanched spinach the activation energy $\left(19.71 \mathrm{~kJ} \mathrm{~mol}^{-1}\right)$ is lower than the corresponding in this work. These variations are maybe related to the differences in the raw material, modelling methodologies and the temperature ranges. It should be emphasized that the one-step modelling procedure used in this work, minimizes the colinearity between parameters.

The raw watercress presented an initial content of chlorophyll $a, b$ and total chlorophylls of $602.821 \pm 120.083 \mu \mathrm{g} \mathrm{g}^{-1}$, $246.213 \pm 27.235 \mu \mathrm{g} \mathrm{g}^{-1}$ and $849.034 \pm 141.574 \mu \mathrm{g} \mathrm{g} \mathrm{g}^{-1}$, 

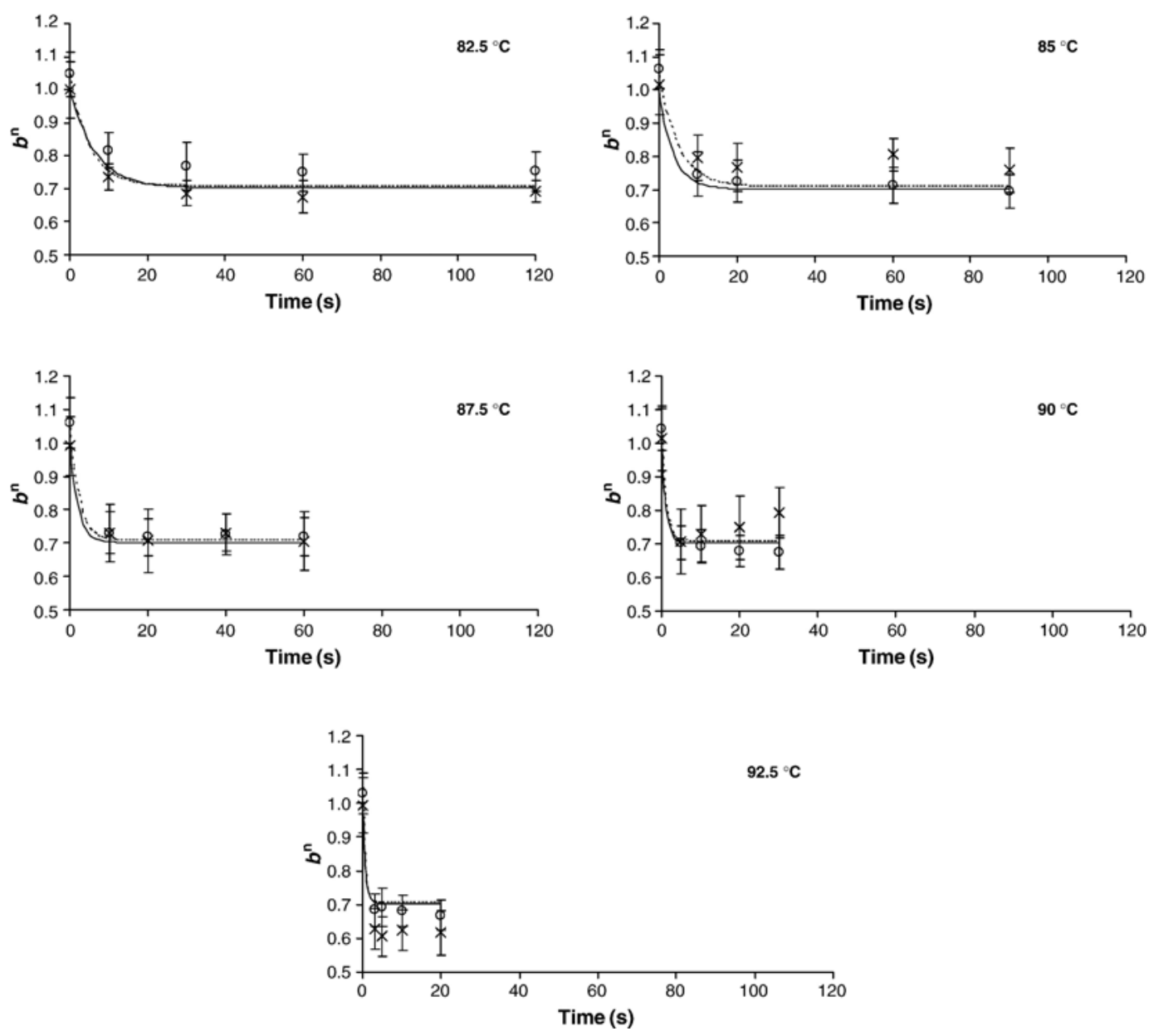

Fig. 3. Effect of temperature, ultrasound and time on $b^{\mathrm{n}}$ parameter of watercress, in the temperature range of 82.5 to $92.5^{\circ} \mathrm{C}$ : (x) experimental values with heat blanching processes; (-) model predicted values for heat blanching processes; (o) experimental values with thermosonication blanching processes; (---) model predicted values for thermosonication blanching processes. Bars represent mean \pm standard deviation.

respectively (Table 1). These results are in agreement with Bohn, Walczyk, Leisibach, and Hurrell (2004), that reported for raw spinach a total chlorophylls content of $790 \mu \mathrm{g} \mathrm{g} \mathrm{g}^{-1}$. Nevertheless, these are higher than the values of $68 \mu \mathrm{g} \mathrm{g}^{-1}$ for chlorophyll $a$ and $29 \mu \mathrm{g} \mathrm{g}^{-1}$ for chlorophyll $b$ in raw green beans (Oruña-Concha, González-Castro, López-Hernández, \& Simal-Lozano, 1997). Murcia et al. (2000) determined in raw broccoli florets $110 \mu \mathrm{g} \mathrm{g}^{-1}$ and $43 \mu \mathrm{g} \mathrm{g}^{-1}$ of chlorophyll $a$ and $b$, respectively, and $36 \mu \mathrm{g} \mathrm{g}^{-1}$ and $18 \mu \mathrm{g} \mathrm{g}^{-1}$, respectively, in raw broccoli stems. The estimated chlorophylls $a: b$ ratio in raw watercress was approximately 2.4:1. This value is in the same range of those reported by Weemaes et al. (1999) for untreated broccoli juice, 2.9:1, and Vernon (1960) for broccoli spears, 2.4:1.

Fig. 5 presents the final watercress normalised total chlorophylls at the different studied temperatures for heat and thermosonication blanching.

The reported results are in agreement with those by Luaces, Pérez, García, and Sanz (2005), where chlorophyll content increased during blanching. Lisiewska, Kmiecik, and Slupski (2004) presented higher values of chlorophylls in blanched dill $( \pm 1350 \mathrm{mg} / 100 \mathrm{~g})$ compared with raw samples $( \pm 1150 \mathrm{mg} /$
$100 \mathrm{~g}$ ). Higher values of other pigments in blanched broccoli and spinach were also reported by Khachik et al. (1992). Granado, Olmedilla, Blanco, and Hidalgo (1992) reported higher values of carotenoids in blanched artichokes, Brussels sprouts, green beans, asparagus, green peppers and spinach, when compared with raw samples. Choe, Lee, Park, and Lee (2001), in a study with spinach, observed an increase of $8 \%$ of chlorophylls in blanched samples $\left(2 \mathrm{~min} ; 100^{\circ} \mathrm{C}\right)$, when compared with raw samples.

Bushway and Wilson (1982), Khachik and Beecher (1987), Varo, Mattila, Piironen, Nironen, and Koivistoinen (1987), Lisiewska et al. (2004) concluded that heat treatment is responsible for the increase in chemical extractability of carotenoids. In this study, the initial increase of the chlorophyll content can also be related to the higher extractability of chlorophylls in the disrupted tissue of the blanched watercress (Fig. 5), since chlorophylls and carotenoids are located in the same region of the chloroplasts, the thylakoid membrane (Heaton \& Marangoni, 1996). Nevertheless, in the extraction method the samples were washed until the residue of centrifugation was decolourised. Preliminary tests, which were run at $85^{\circ} \mathrm{C}$, showed the mentioned behaviour; after a slight initial increase, the amounts of chlorophylls were practically maintained throughout 

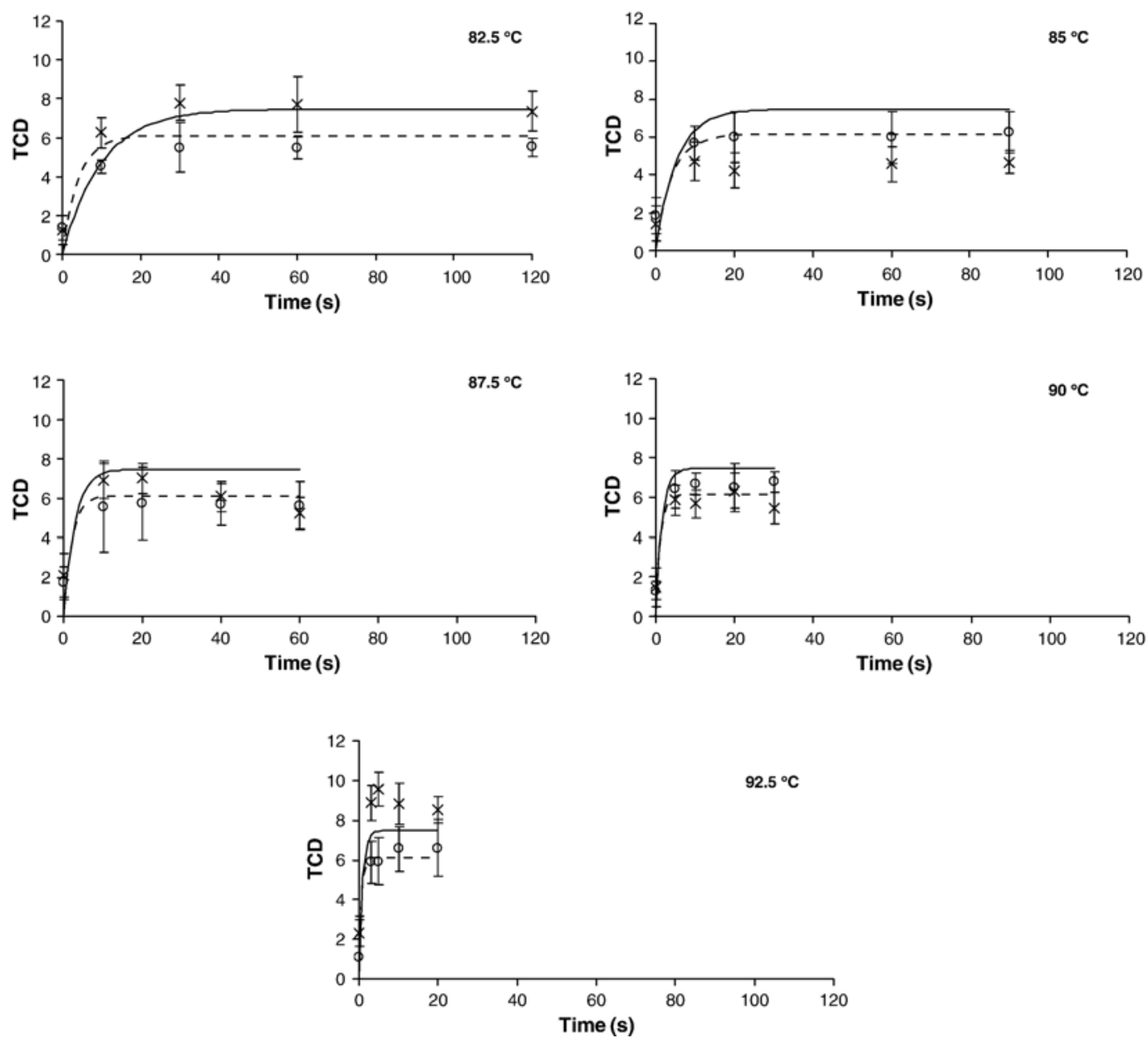

Fig. 4. Effect of temperature, ultrasound and time on TCD parameter of watercress, in the temperature range of 82.5 to $92.5{ }^{\circ} \mathrm{C}$ : $(\mathrm{x})$ experimental values with heat blanching processes; (-) model predicted values for heat blanching processes; (o) experimental values with thermosonication blanching processes; (---) model predicted values for thermosonication blanching processes. Bars represent mean \pm standard deviation.

$30 \mathrm{~min}$. The same results were reported by Song, An, and Kim (2003), in which the content of chlorophylls was approximately maintained along blanching soybeans at $80{ }^{\circ} \mathrm{C}$ during $30 \mathrm{~min}$.

Table 2

Kinetic parameters of colour changes due to heat blanching

\begin{tabular}{lcccc}
\hline Kinetic & \multicolumn{4}{c}{ Colour parameter } \\
\cline { 2 - 5 } parameter & $L^{\mathrm{n}}$ & $a^{\mathrm{n}}$ & $b^{\mathrm{n}}$ & $\mathrm{TCD}$ \\
\hline$C_{0_{\mathrm{H}}}$ & $1.00 \pm 0.01$ & $0.96 \pm 0.01$ & $1.00 \pm 0.02$ & 0 \\
$C_{\mathrm{e}_{\mathrm{H}}}$ & $0.87 \pm 0.003$ & $1.01 \pm 0.02$ & $0.70 \pm 0.01$ & $7.47 \pm 0.30$ \\
$E_{\mathrm{a}_{\mathrm{H}}\left(\mathrm{kJ} \mathrm{mo \Gamma}{ }^{1}\right)}$ & $209.41 \pm 67.37$ & $422.37 \pm 126.62$ & $249.31 \pm 197.91$ & $267.16 \pm 113.28$ \\
$k_{\mathrm{H}_{87.5}{ }^{\circ}\left(\mathrm{s}^{-1}\right)}$ & $0.44 \pm 0.13$ & $0.028 \pm 0.024$ & $0.5 \pm 0.44$ & $0.35 \pm 0.17$ \\
$R_{\mathrm{H}}^{2}$ & 0.99 & 0.99 & 0.99 & 0.92 \\
\hline
\end{tabular}

Table 3

Kinetic parameters of colour changes due to thermosonication blanching

\begin{tabular}{lcccc}
\hline Kinetic & \multicolumn{4}{c}{ Colour parameter } \\
\cline { 2 - 5 } parameter & $L^{\mathrm{n}}$ & $a^{\mathrm{n}}$ & $b^{\mathrm{n}}$ & $\mathrm{TCD}$ \\
\hline$C_{0_{\mathrm{Ts}}}$ & $0.99 \pm 0.01$ & $1.01 \pm 0.01$ & $1.05 \pm 0.01$ & 0 \\
$C_{\mathrm{e}_{\mathrm{Ts}}}$ & $0.86 \pm 0.003$ & $1.09 \pm 0.01$ & $0.71 \pm 0.01$ & $6.12 \pm 0.15$ \\
$E_{\mathrm{a}_{\mathrm{Ts}}}\left(\mathrm{kJ} \mathrm{mor}^{1}\right)$ & $235.83 \pm 89.32$ & $187.70 \pm 160.07$ & $330.62 \pm 128.16$ & $281.80 \pm 190.25$ \\
$k_{\mathrm{Ts}_{87.5}{ }^{\circ}}\left(\mathrm{s}^{-1}\right)$ & $0.42 \pm 0.16$ & $0.28 \pm 0.18$ & $0.44 \pm 0.23$ & $0.47 \pm 0.32$ \\
$R_{\mathrm{Ts}}^{2}$ & 0.99 & 0.99 & 0.99 & 0.96 \\
\hline
\end{tabular}

On the other hand, Schwartz and von Elbe (1983) reported slightly lower chlorophylls content in blanched spinach than in raw samples, probably due to the leaching into the blanching medium. The results in Fig. 5 are similar to those reported by Agüero, Pereda, Roura, Moreira, and del Valle (2005), who found no great effect on chlorophylls content during blanching of Swiss chard; its retention being significantly lower than $100 \%(96.1 \pm 5.5 \%)$ only when blanched for $120 \mathrm{~s}$ in boiling water. The same phenomenon was observed by Ihl et al. (1998),

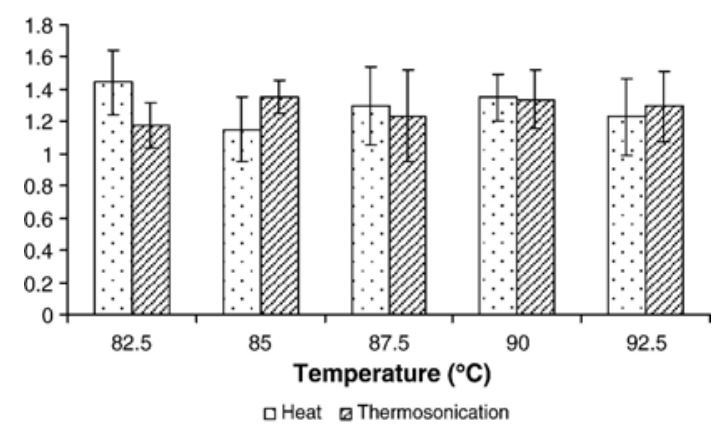

Fig. 5. Final watercress normalised total chlorophylls content for heat and thermosonication at each temperature. Bars represent mean \pm standard deviation. 


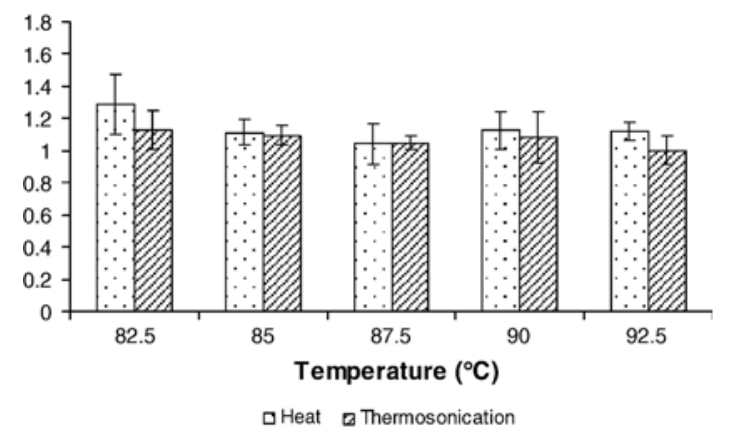

Fig. 6. Final watercress normalised total pheophytins content for heat and thermosonication at each temperature. Bars represent mean \pm standard deviation.

who studied chlorophylls changes after blanching artichokes in boiling water, steam or microwave blanching. Boiling water blanching retained the total quantity of chlorophyllous pigments throughout $10 \mathrm{~min}$. Oruña-Concha et al. (1997) observed that chlorophyll $a$ and $b$ contents in blanched padron peppers $\left(100{ }^{\circ} \mathrm{C}, 4 \mathrm{~min}\right)$ decreased by 13 and $28 \%$, respectively. Turkmen, Poyrazoglu, Sari, and Velioglu (2006) reported values of chlorophylls retention of $19-100 \%$, depending on the vegetable type and cooking method, and Viña et al. (2007), in a work with Brussels sprouts, observed also higher values of chlorophylls in the blanched samples $\left(1 \mathrm{~min}\right.$ and $\left.3 \mathrm{~min}, 100{ }^{\circ} \mathrm{C}\right)$.

The chlorophyll content is highly dependent on the kind of vegetable and chlorophyll distribution in the plant, and also on the methodologies used for the study.

As the applied heat and thermosonication treatments (even with $30 \mathrm{~min}$ at $85{ }^{\circ} \mathrm{C}$ ) did not promote any significant degradation in the chlorophylls content, the initial increase and the behaviour throughout the blanching time was not relevant for modelling.

After a certain initial increase the pheophytins content was maintained throughout the blanching time. Fig. 6 presents the final normalised pheophytins content for the studied temperatures with heat and thermosonication treatments. This initial increase of pheophytins is proportional to chlorophylls content. This could indeed indicate that pigments are more extracted from the processed tissue, as already explained above. This suggests that no significant conversion of chlorophylls to pheophytins occurred. The presence of pheophytins in the raw samples is maybe due to some conversion of chlorophylls to pheophytins related to harvesting and handling. Likewise, this is in accordance with the mere eye observation, that no olive-brown colour after blanching was detected. Colour evaluation by colorimetry is also in agreement with these results, since the samples after blanching became greener ( $a$ value) and less yellow ( $b$ value).

\section{Conclusion}

The reaction rates of watercress colour changes due to heat and thermosonication blanching were the same, independently of the treatment, for all colour parameters, except for $a$ value. These results indicated that the use of ultrasounds only promote, at a higher rate, changes of the green colour. On the other hand, the TCD parameter showed no significant differences $(P>0.05)$ between treatments. Thus, it is crucial to analyse all the colour parameters separately, once differences in one parameter between treatments might not be detected by the TCD values. Therefore, the TCD parameter is not always reliable by itself.

The chlorophyll analyses indicated, in both processes, an increase in all the blanched samples, however not significant $(P>0.05)$ in comparison to the raw samples. Thus, no degradation of the pigments occurred during heat or thermosonication treatments. By colorimetry, the blanched samples were greener ( $a$ value), indicating that this type of measurements can be a useful tool to determine colour changes, instead of more expensive and time-consuming methods.

Once in a previous work (Cruz et al., 2006) thermosonication blanching proved to be an efficient method for watercress peroxidase inactivation, it appears that this treatment is useful to minimize processing extent and undesirable colour changes.

Therefore, the present findings will help to optimize the design of watercress blanching conditions with heat and thermosonication.

\section{Nomenclature \\ A Absorbance \\ a Colour co-ordinate, represents red to green \\ $b \quad$ Colour co-ordinate, represents blue to yellow \\ $C \quad L, a, b$ or TCD parameter at time $\mathrm{t}$ \\ $E_{\mathrm{a}} \quad$ Activation energy $\left(\mathrm{kJ} \mathrm{mol}^{-1}\right)$ \\ $k \quad$ Reaction rate $\left(\mathrm{s}^{-1}\right)$ \\ $L \quad$ Colour co-ordinate, represents black to white \\ $R \quad$ Universal gas constant $\left(8.314 \mathrm{~J} \mathrm{~mol}^{-1} \mathrm{~K}^{-1}\right)$ \\ $t \quad$ Time (s) \\ $T \quad$ Absolute temperature (K) \\ TCD Total colour difference parameter}

\section{Superscripts \\ $\mathrm{n} \quad$ Normalised value}

\section{Subscripts}

e Value at equilibrium

$\mathrm{H} \quad$ Relative to heat blanching

Ts Relative to thermosonication blanching

ref At the reference temperature

$0 \quad$ Initial value at time equal to zero

$87.5^{\circ} \mathrm{C}$ At the reference temperature of $87.5^{\circ} \mathrm{C}$

\section{Acknowledments}

The author Rui M. S. Cruz gratefully acknowledges his Ph.D. grant SFRH/BD/9172/2002 to Fundação para a Ciência e a Tecnologia (FCT) from Ministério da Ciência e do Ensino Superior. The authors thank the Vitacress Company for supplying the raw watercress.

\section{References}

Agüero, M. V., Pereda, J., Roura, S. I., Moreira, M. R., \& del Valle, C. E. (2005). Sensory and biochemical changes in Swiss chard (Beta vulgaris) during blanching. Lebensmittel-Wissenschaft und Technologie, 38, 772-778. 
Ahmed, J., Kaur, A., \& Shivhare, U. (2002). Color degradation kinetics of spinach, mustard leaves, and mixed puree. Journal of Food Science, 67(3), 1088-1091.

Arabshahi, A., \& Lund, D. B. (1985). Considerations in calculating kinetics parameters from experimental data. Journal of Food Processing and Engineering, 7, 239-251.

Ávila, I. M. L. B., \& Silva, C. L. M. (1999). Modelling kinetics of thermal degradation of colour in peach puree. Journal of Food Engineering, 39, 161-166.

Baik, O. D., \& Mittal, G. S. (2003). Kinetics of tofu color changes during deepfat frying. Lebensmittel-Wissenschaft und Technologie, 36, 43-48.

Barreiro, J. A., Milano, M., \& Sandoval, A. J. (1997). Kinetics of colour change in double concentrated tomato paste during thermal treatment. Journal of Food Engineering, 33, 359-371.

Bohn, T., Walczyk, T., Leisibach, S., \& Hurrell, R. F. (2004). Chlorophyll-bound magnesium in commonly consumed vegetables and fruits: Relevance to magnesium nutrition. Journal of Food Science, 69(9), 347-350.

Bowers, J. (1992). In J. Bowers (Ed.), Food theory and applications (pp. 738-739). New York: Macmillan Publisher.

Brewer, M. S., Begum, S., \& Bozeman, A. (1995). Microwave blanching effects on chemical sensory and color characteristics of frozen broccoli. Journal of Food Quality, 18, 461-474.

Bushway, R. J., \& Wilson, A. M. (1982). Determination of $\alpha$ - and $\beta$-carotene in fruit and vegetables by high performance liquid chromatography. Canadian Institute of Food Science and Technology Journal, 15, 165-169.

Choe, E., Lee, J., Park, K., \& Lee, S. (2001). Effects of heat pre-treatment on lipid and pigments of freeze-dried spinach. Journal of Food Science, 66(8), 1074-1079.

Cruz, R. M. S., Vieira, M. C., \& Silva, C. L. M. (2006). Effect of heat and thermosonication treatments on peroxidase inactivation kinetics in watercress (Nasturtium officinale). Journal of Food Engineering, 72(1), 8-15.

Di Cesare, L. F., Forni, E., Viscardi, D., \& Nani, R. C. (2004). Influence of drying techniques on the volatile phenolic compounds, chlorophyll and colour of oregano (Origanum vulgare L. ssp. prismaticum Gaudin). Italian Journal of Food Science, 2(16), 165-175.

Francis, F. J., \& Clydesdale, F. H. (1975). Food colorimetry. Theory and applications (pp. 130-142). Westport, CT: AVI Publishing.

Granado, F., Olmedilla, B., Blanco, I., \& Hidalgo, E. R. (1992). Carotenoid composition in raw and cooked Spanish vegetables. Journal of Agricultural and Food Chemistry, 40, 2135-2140.

Health Canada-Official Method (1999). T-310-Determination of whole tobacco pH. Ottawa, Canada.

Heaton, J. W., \& Marangoni, A. G. (1996). Chlorophyll degradation in processed foods and senescent plant tissues. Trends in Food Science and Technology, 7, $8-15$.

Hunter Lab (2000). Applications Notes, 12(5), 1-8.

Ibarz, A., Pagán, J., \& Garza, S. (1999). Kinetic models for colour changes in pear puree during heating at relatively high temperatures. Journal of Food Engineering, 39, 415-422.

Icier, F., Yildiz, H., \& Baysal, T. (2006). Peroxidase inactivation and colour changes during ohmic blanching of pea puree. Journal of Food Engineering, 74(3), 424-429.

Ihl, M., Monsalves, M., \& Bifani, V. (1998). Chlorophyllase inactivation as a measure of blanching efficacy and colour retention of Artichokes (Cynara scolymus L.). Lebensmittel-Wissenschaft und Technologie, 31, 50-56.

Katsaboxakis, K. Z. (1984). The influence of the degree of blanching on the quality of frozen vegetables. In P. Zeuthen, J. C. Cheftel, C. Eriksson, M. Jul, H. Leniger, P. Linko, G. Varela, \& G. Vos (Eds.), Thermal processing and quality of foods (pp. 559-578). : Elsevier Applied Science Publishers LTD.

Khachik, F., \& Beecher, G. R. (1987). Application of a C-45- $\beta$-carotene as an internal standard for the quantification of carotenoids in yellow/orange vegetables by liquid chromatography. Journal of Agricultural and Food Chemistry, 35, 732-738.

Khachik, F., Goli, M. B., Beecher, G. R., Holden, J., Lusby, W. R., Tenorio, M. D., \& Barrera, M. R. (1992). Effect of food preparation on qualitative and quantitative distribution of major carotenoid constituents of tomatoes and several green vegetables. Journal of Agricultural and Food Chemistry, 40, 390-398.

Knorr, D., Zenker, M., Heinz, V., \& Lee, D. (2005). Applications and potential of ultrasonics in food processing. Trends in Food Science and Technology, 15(5), 261-266.
Lau, M. H., Tang, J., \& Swanson, B. G. (2000). Kinetics of textural and color changes in green asparagus during thermal treatments. Journal of Food Engineering, 45, 231-236.

Lin, S., \& Brewer, M. S. (2005). Effects of blanching method on the quality characteristics of frozen peas. Journal of Food Quality, 28(4), 350-360.

Lisiewska, Z., Kmiecik, W., \& Slupski, J. (2004). Contents of chlorophylls and carotenoids in frozen dill: effect of usable part and pre-treatment on the content of chlorophylls and carotenoids in frozen dill (Anethum graveolens L.), depending on the time and temperature of storage. Food Chemistry, 84, 511-518.

Luaces, P., Pérez, A. G., García, J. M., \& Sanz, C. (2005). Effects of heattreatments of olive fruit on pigment composition of virgin olive oil. Food Chemistry, 90, 169-174.

Luh, B.S., \& Woodroof, J.G. (1988). Commercial vegetable processing (pp. 180 181, 199-200, 672-673). New York: Van Nostrand Reinhold Company.

Martins, R. C., \& Silva, C. L. M. (2002). Modelling colour and chlorophyll losses of frozen green beans (Phaseolus vulgaris L.). International Journal of Refrigeration, 25, 966-974.

Mason, T. J., Paniwnyk, L., \& Lorimer, J. P. (1996). The uses of ultrasound in food technology. Ultrasonics Sonochemistry, 3, 253-260.

Murcia, M. A., López-Ayerra, B., Martnez-Tomé, M., \& García-Carmona, F. (2000). Effect of industrial processing on chlorophyll content of broccoli. Journal of the Science of Food and Agriculture, 80, 1447-1451.

Nisha, P., Singhal, R. S., \& Pandit, A. B. (2004). A study on the degradation kinetics of visual green colour in spinach (Spinacea oleracea L.) and the effect of salt therein. Journal of Food Engineering, 64, 135-142.

Oruña-Concha, M. J., González-Castro, M. J., López-Hernández, J., \& SimalLozano, J. (1997). Effects of freezing on the pigment content in green beans and pardon peppers. Zeitschrift fur Lebensmittel-Untersuchung und Forschung, 205, 148-153.

Priestley, R. J. (1979). Effects of heating on foodstuffs (pp. 307-314). London: Applied Science Publishers Ltd.

Rattanathanalerk, M., Chiewchan, N., \& Srichumpoung, W. (2005). Effect of thermal processing on the quality loss of pineapple juice. Journal of Food Engineering, 66, 259-265.

Rocha, T., Lebert, A., \& Marty-Audouin, C. (1993). Effect of pretreatments and drying conditions on drying rate and colour retention of basil. LebensmittelWissenschaft und Technologie, 26, 456-463.

Schwartz, S. J., \& von Elbe, J. H. (1983). Kinetics of chlorophyll degradation to pyropheophytin in vegetables. Journal of Food Science, 48, 1303-1306.

Song, J., An, G., \& Kim, C. (2003). Color, texture, nutrient contents, and sensory values of vegetable soybean [Glycine $\max$ (L.) Merrill] as affected by blanching. Food Chemistry, 83, 69-74.

Stata Corporation (1999). Stata Statistical Software: Release 6.0 college station.

Tijskens, L. M. M., Schijvens, E. P. H. M., \& Biekman, E. S. A. (2001) Modelling the change in colour of broccoli and green beans during blanching. Innovative Food Science and Emerging Technologies, 2, 303-313.

Turkmen, N., Poyrazoglu, E. S., Sari, F., \& Velioglu, Y. S. (2006). Effects of cooking methods on chlorophylls, pheophytins and colour of selected green vegetables. International Journal of Food Science and Technology, 41(3), 281-288.

Varo, P., Mattila, M., Piironen, V., Nironen, P., \& Koivistoinen, P. (1987) Effects on food preparation of natural antioxidant levels in foods. II World Congress of Food Technology, Advances in food technology, Barcelona, March 1987.

Vercet, A., Burgos, J., Crelier, S., \& Lopez-Buesa, P. (2001). Inactivation of proteases and lipases by ultrasound. Journal of Innovative Food Science and Emerging Technologies, 2, 139-150.

Vernon, L. P. (1960). Spectrophotometric determination of chlorophylls and pheophytins in plant extracts. Analytical Chemistry, 32(9), 1144-1150.

Viña, S. Z., Olivera, D. F., Marani, C. M., Ferreyra, R. M., Mugridge, A., Chaves, A. R., et al. (2007). Quality of Brussels sprouts (Brassica oleracea L. gemmifera DC) as affected by blanching method. Journal of Food Engineering, $80,218-225$.

Weemaes, C. A., Ooms, V., Van Loey, A. M., \& Hendrickx, M. E. (1999). Kinetics of chlorophyll degradation and color loss in heated broccoli juice. Journal of Agricultural and Food Chemistry, 47, 2404-2409.

Woolfe, M. L. (1979). Pigments. In R. J. Priestley (Ed.), Effect of heat processing on foodstuffs (pp. 76-120). London: Applied Science Publishers Ltd. 